\title{
LATE WINTER FEEDING STIMULATES RAPID SPRING DEVELOPMENT OF CARNIOLAN HONEY BEE COLONIES (APIS MELLIFERA CARNICA)
}

Puškadija, Z. (1), Spiljak, L.(2), Kovačić, M.(1)

\section{SUMMARY}

Unfavourable weather conditions after the queen starts with intensive oviposition during early spring may cause an imbalance in the division of tasks among worker bees in the bee colony. This can lead to slow spring development and poor exploitation of the main spring nectar flows. In order to accelerate the spring development, it is necessary, as a technological measure, to feed supplemental candy to bee colonies. In this research, the necessity of supplemental feeding, as well as the composition of candy (pollen and protein substitute) were analysed. Three groups of ten bee colonies each were formed - the control, unfed group, pollen candy fed and protein substitute candy fed. In the period from 22/02/2016 and 04/04/2016 three control measurements were performed during which the number of bees, the number of brood cells and weight of the bee colonies were determined. The research has shown that supplemental feeding of the bee colony in late winter in order to encourage the rapid spring development is justified. Namely, at the final measurements in April, the results showed differences between groups. The treated colonies had higher net hive weight, a greater number of bees and statistically significantly more brood cells. The results of this study confirm that the technological measure of supplemental feeding in late winter should be performed on all commercial apiaries for the production of honey, pollen, royal jelly, queen bees and bee venom.

Key-words: supplemental feeding, honey bee, colony spring development

\section{INTRODUCTION}

Climate change caused significant changes in seasonal honey bee foraging activity of continental Croatia. Namely, since 2005, 67\% of nectar flow happens during spring, which is an increase in the share of spring forage in total annual honey production by $24.2 \%$. The remaining $33 \%$ of nectar flow takes place in the summer and that intake is very often absent because of the very high daily temperatures and lack of precipitation caused by climate change (Puškadija, 2011). In such conditions, earlier spring colonies development seems to be reasonable, so that bees can take better advantage of early spring nectar flow. To achieve this goal, full and proper division of labour among worker bees in the bee colony is required, which can be achieved in strong colonies and in moderate conditions of nectar intake along with sufficient food supply in the hive. Winter reserves of pollen in hives play an important role during winter when colonies start with brood rearing and there is no intake of pollen (Seeley and Visscher, 1985). Sufficient and balanced food ensures normal development of healthy bee colonies (Brodschneider and Crailsheim, 2010) and its lack in the bee colony can restrict its development (Khoury et al., 2013), especially in spring when the division of labour among worker bees is in the most sensitive stage (Standifer et al., 1973). When the food

(1) Prof. Dr. Zlatko Puškadija (pzlatko@pfos.hr), Marin Kovačić, Ph.D. student - Josip Juraj Strossmayer University of Osijek, Faculty of Agriculture in Osijek, Vladimira Preloga 1, 31000 Osijek, Croatia, (2) Lejla Spiljak, M. Bacc. Agr., University of Sarajevo, Faculty of Agriculture and Food Sciences, Zmaja od Bosne 8, 71000 Sarajevo, Bosnia and Herzegovina 
supplies in the hive become scarce, the number of forager bees increases so that young bees skip some stages of the division of labour in the hive (nurse bees - care of the brood) by becoming foragers (Schulz et al., 1998). Bad weather conditions during intensive brood rearing in spring may cause significantly reduced pollen intake and if pollen reserves are consumed, brood rearing may be decreased or even suspended (Imdorf et al., 1998). These unwanted scenarios in the development of colonies could be prevented by stimulative feeding of colonies at the right time. Late summer stimulative feeding ensures enough wintering bees which ensure the proper development in the spring. Colonies prepared for overwintering in this way respond well to stimulative feeding in late winter. The objective of the experiment was to measure the effectiveness of supplemental feeding with pollen and protein substitute candy to the colonies in the spring period in order to accelerate their spring development.

\section{MATERIAL AND METHODS}

The experiment was conducted in apiary at

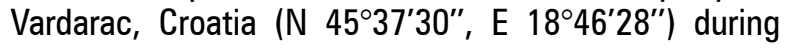
spring of 2016. A total of 30 bee colonies with Carniolan bees (Apis mellifera carnica) set in Langstroth hives were divided into three groups of 10 . All test colonies were formed on the same day, May 15, 2015, that ensured the equal strength of all bee colonies in the experiment. The nucs were formed with queens of the same age, reared on the same day and from the same mother line. From February 22, 2016 until April 4, 2016, repeated measures every 21 days were conducted three times where the bee colonies weight, number of bees and number of brood cells were determined according to Liebefeld method (Imdorf et al., 1987). The bee colonies were weighed using the scale of $100 \mathrm{~g}$ accuracy. Before the feeding, the first colonies measurements were made: weight, the number of bees and the number of brood cells were estimated in mid-February 2016. Supplemental feeding of colonies started on February 22 with 2 different supplements: group P colonies were fed with pollen candy; group $S$ colonies were fed with protein substitute candy while control group $C$ colonies were not fed at all. Pollen candy was made of powder sugar and enzyme inverted syrup mixed with $5 \%$ of sterilized pollen. Protein substitute candy was composed of enzyme inverted syrup, inactivated brewer's yeast $(50 \%$ proteins) and defatted soybean flour (44\% proteins). From the period when the temperatures in February rose until the fruit trees blossom, the test groups were supplemented with the candy ad libitum and replaced as colonies had consumed it.

\section{Statistical analysis}

One-way ANOVA and Tukey's post-hoc test were used to determine differences among groups. Spearman correlation coefficient was used to determine correlation between number of bees, brood cells and weight of colonies. For statistical data analysis, SPSS program version 20 (SPSS Inc., Chicago) was used.

\section{RESULTS}

\section{Weight of bee colonies}

Control group colonies (C) had a higher net mass at the beginning of the experiment, but not statistically significant. While it is common for a bee colony to lose some mass in the spring period, at the end of experiment this happened only in group $C$ that was not supplementally fed. Group P, which was supplementally fed pollen candy during spring, had an average mass gain of $2 \mathrm{~kg}$, while the group $S$ gained an average of $0.54 \mathrm{~kg}$ per hive (Figure 1).

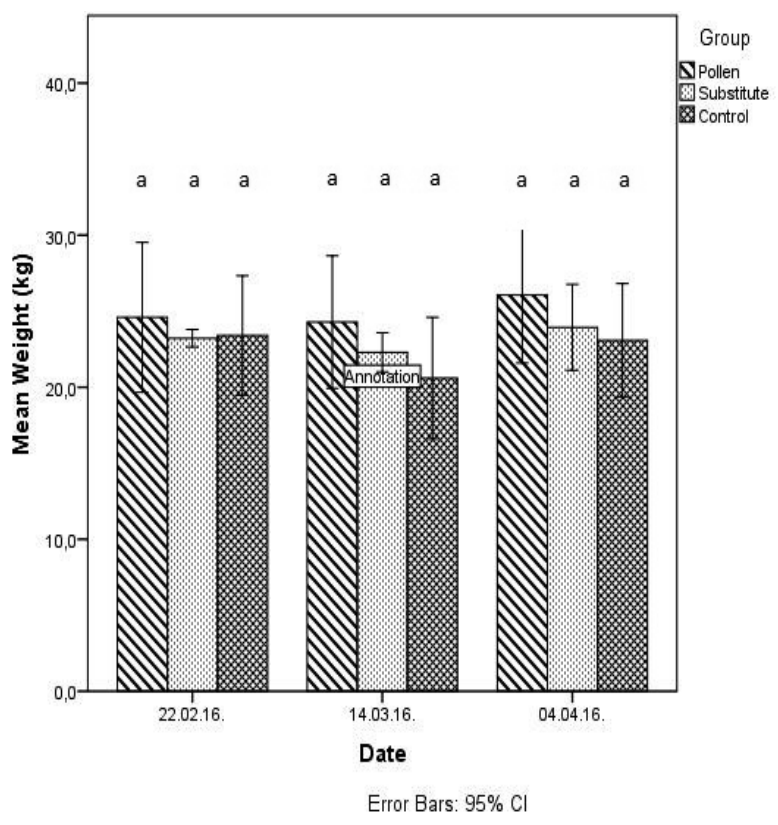

Different letters represent statistical difference $(p<0.05)$

Različita slova označavaju statističku razliku $(p<0,05)$

Figure 1. Average weight of colonies between experimental groups

Slika 1. Prosječna masa pčelinjih zajednica između pokusnih skupina

\section{Number of bees}

At the start of the study (February) there was no significant difference among groups. The highest average number of bees was found in group $C$ and the lowest in group P. Results of the second measurement (March) also showed no significant difference in the number of bees among the groups, with the highest average number of bees in group $C$.

During the third measurement (April) the most evident, but not a statistical difference among groups was observed where group $S$ had the largest and control group the smallest number of bees (Figure 2). 


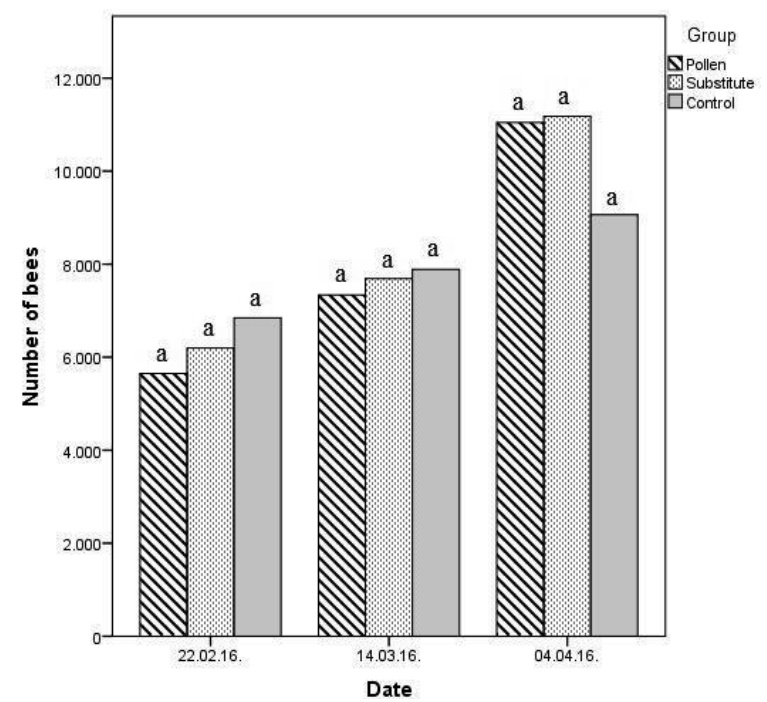

Different letters represent statistical difference $(p<0.05)$

Različita slova označavaju statističku razliku $(p<0,05)$

Figure 2. The number of bees during the spring between experimental groups

Slika 2. Broj pčela tijekom proljeća između pokusnih skupina

\section{Number of brood cells}

During the first measurement of the amount of brood (February) in bee colonies, there was no statistically significant difference between the groups showing the uniform strength of colonies at the beginning of the experiment (Figure 3).

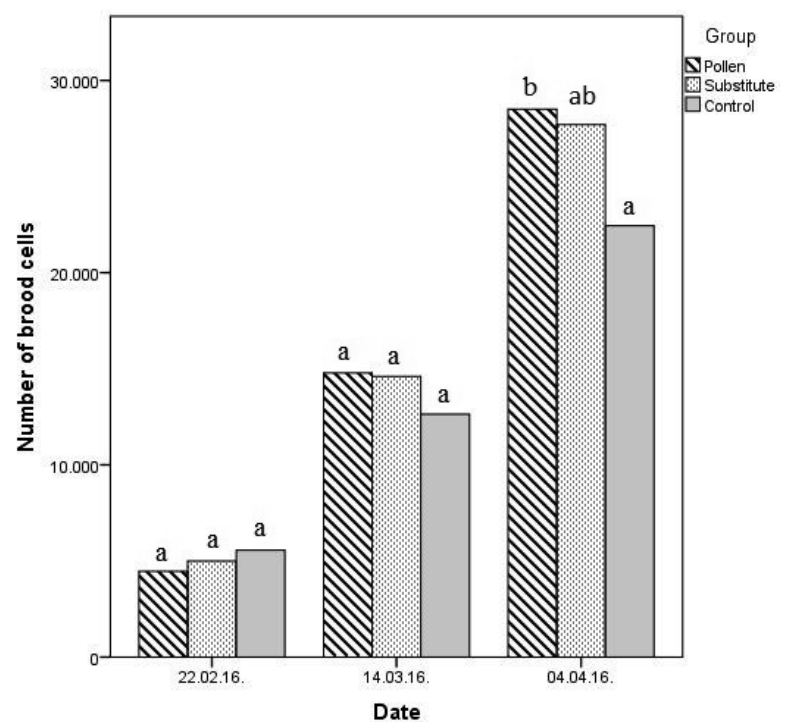

Different letters represent statistical difference $(p<0.05)$

Različita slova označavaju statističku razliku $(p<0,05)$

Figure 3. The increase in the number of brood cells during spring between experimental groups

Slika 3. Broj stanica legla tijekom proljeća između pokusnih skupina
The highest average number of brood cells was found in group C, and the lowest in group P (Fig. 3). During the second measurement (March) the significant positive effect of supplemental feeding was observed, as the highest number of brood was noted in group $\mathrm{P}$, and the lowest in group $\mathrm{C}$. It was not until the third measurement (April) that the statistically significant differences among groups were determined, $F(2.27)=3.607$, $p=0.042$. A significantly higher number of brood cells was determined in group $P(p<0.05)$ than in control group. Although a much higher number of brood cells was counted in group $S$ than in group $C$, no statistical difference was noted (Fig. 3) No statistically significant difference was determined between groups $P$ and $S$.

$A$ very high and significant positive correlation $(r=0.83, p<0.01)$ was found between the number of bees and number of brood cells (Figure 4). Also, significant but lower correlations were determined between the number of bees and weight of the colonies $(r=0.38$, $p<0.01)$ and the number of brood cells and weight of the colonies $(r=0.23, p<0.05)$.

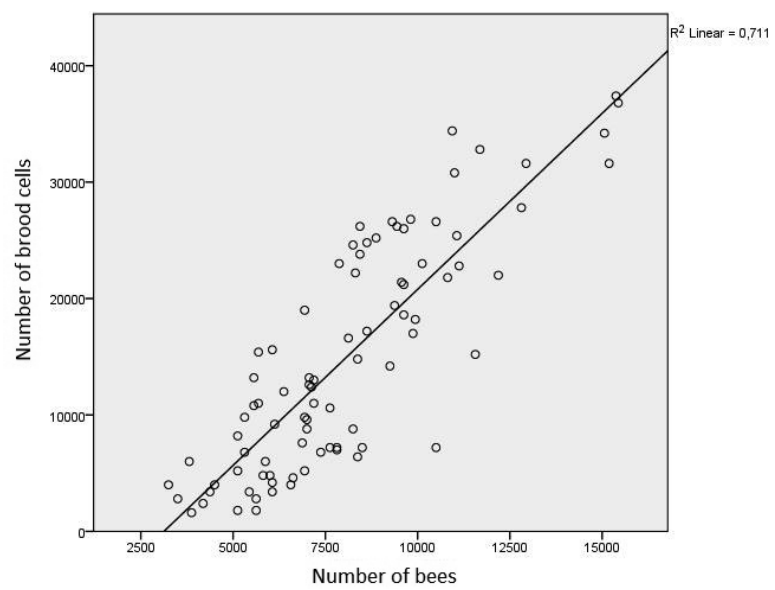

Figure 4. Correlation between the number of bees and the number of brood cells

Slika 4. Korelacija između broja pčela i broja stanica legla

\section{DISCUSSION}

The complete absence, shortage or even poor quality of pollen results in slower growth and reduced weight of young bees, shortened life span of bees and insufficient production of royal jelly that is required for normal growth and development of larvae (Schmidt et at., 1995; Di Pasquale et al. 2013). All of these effects together may result in a slow and insufficient development of bee colonies. On the other hand, according to Gerula (2004), colonies that are stronger at the beginning of May have a higher honey production.

Although the control group at the beginning of the experiment had most bees and brood cells, clear effect of stimulative feeding was confirmed during last measurement at the beginning of April, where two fed groups had more bees and brood cells. Dynamic of spring development is one of the main positive traits of carniolan bee colonies (Ruttner, 1988) and gives them 
time opportunity to gain full strength in the late spring. As climate changes cause earlier plant blooming in spring (Godow et al., 2017; Hidalgo-Galvez et al., 2017) and often hot, dry summers, dynamic development of colonies in spring is crucial.

One of the reasons why fed colonies were growing faster could be explained with relatively bad weather conditions during March, where 17 rainy days were recorded. Since a significant impact of the year and location on the bee colonies development was observed (Hatjina et al., 2014), beekeepers have to be prepared both for the fruitful and poor spring conditions. Cold and rainy weather conditions influence lower foraging activity, pollen intake and consequently colony productivity (Mattila and Otis, 2006). Pollen shortage in colonies could lead to utilization of nutritional body reserves of worker bees (Crailsheim, 1990) and consequently, brood development could be significantly diminished. Unfavourable weather conditions that may occur during spring and slow down colony build-up is one of the reasons why supplemental late winter feeding should be applied in apiaries. Later on during summer, unfed colonies mainly will reach the strength of fed colonies (Mattila and Otis, 2006), but spring nectar flows will not be properly exploited.

The results obtained experimentally, whether relating to the increase in the number of bees or brood cells in bee colonies during early spring, show a significant increase in the measured parameters in the group fed with pollen candy. We observed that colonies preferably consumed pollen substitute over stimulative protein candy, which is also noticed by Saffari et al. (2010). These findings match those in the research of Madras-Majewska et al. (2005), according to which supplemental bee feeding with pollen substitutes was of great importance for a bee colony during the early spring when pollen from nature is not available. According to the same authors, supplemental feeding of pollen and pollen substitutes at a time when pollen is abundant in nature is unnecessary. Akyol et al. (2006) emphasize the significant impact of supplemental feeding with pollen candy on bee colonies compared to unfed colonies. Our experiment confirms the results of Mattila and Otis (2006) who showed that supplemental feeding of pollen has a significant effect in the early spring when it notably encourages the growth of bee colonies through increased production of young worker bees until the first week of May.

\section{CONCLUSION}

The purpose of the research was to determine how beekeepers can cope with climatic changes and new conditions of earlier and shorter nectar flows. The research has shown that the technological measure of supplemental feeding of the bee colony in late winter in order to encourage the rapid spring development is justified, especially during unfavourable weather conditions. Namely, at the final measurements in April, the results showed differences between control and fed groups in all measured parameters, while statistically significantly more brood cells were found in pollen substitute group compared to control group. The results of this study confirm that the technological measure of supplemental feeding in late winter should be performed on all commercial apiaries that are intended for the intensive production of honey, pollen, royal jelly, queen bees and bee venom.

\section{ACKNOWLEDGMENTS}

We are thankful to Karolina Tucak who helped us in field work activities and "Agro Simpa" LLC, Sisak, Croatia, who manufactured the candy used in the experiment.

\section{REFERENCES}

1. Akyol, E., Yeninar, H., Sahinler, N., Guler, A. (2006): The effects of additive feeding and feed additives before wintering on honey bee colony performances, wintering abilities and survival rates at the east Mediterranean region. Pakistan Journal of Biological Sciences, 9: 589-592.

doi: http://dx.doi.org/10.3923/pjbs.2006.589.592

2. Brodschneider, R., Crailsheim, K. (2010): Nutrition and health in honey bees. Apidologie, 41: 278-294.

doi: http://dx.doi.org/10.1051/apido/2010012

3. Crailsheim, K. (1990): The protein balance of the honey bee worker. Apidologie, 21: 417-429.

doi: http://dx.doi.org/10.1051/apido:19900504

4. Di Pasquale, G., Salignon, M., Le Conte, Y., Belzunces, L. P., Decourtye A., Kretzschmar, A., Alaux, C. (2013): Influence of pollen nutrition on honey bee health: Do pollen quality and diversity matter? PLoS ONE, 8(8): e72016.

doi: http://dx.doi.org/10.1371/journal.pone.0072016

5. Gerula, D. (2004): Effects of adjusting the colony structure of caucasioan (Apis mellifera Caucasica Gorb) and carniolan (Apis mellifera carnica Pollm.) bees under different flow conditions. Journal of Apicultural Science, 48(2): 83-95

6. Godow, S.C., Chmielewski, F.M., Bienefeld, K. (2017): Honey bees and climate change. In Programm und Abstract 64. Jahrestagung der $A G$ der Institute für Bienenforschung e.V. (p. 9). Celle - Germany.

7. Hatjina, F., Costa, C., Büchler, R., Uzunov, A., Drazic, M., Filipi, J., Charistos, L., Ruottinen, L., Andonov, S., Meixner, M.D., Bienkowska, M., Dariusz, G., Panasiuk, B., Le Conte, Y., Wilde1, J., Berg, S., Bouga, M., Dyrba, W., Kiprijanovska, H., Korpela, S., Kryger, P., Lodesani, M., Pechhacker, H., Petrov, P., Kezic, N. (2014): Population dynamics of European honey bee genotypes under different environmental conditions. Journal of Apicultural Research, 53(2): 233-247.

doi: http://dx.doi.org/10.3896/IBRA.1.53.2.05

8. Hidalgo-Galvez, M.D., García-Mozo, H., Oteros, J., Mestre, A. Botey, R., Galán, C. (2017): Phenological behaviour of early spring flowering trees in Spain in response to recent climate changes. Theoretical and Applied Climatology, published online

doi: http://dx.doi.org/10.1007/s00704-017-2089-6

9. IBM Corp. Released 2011. IBM SPSS Statistics for Windows, Version 20.0. Armonk, NY: IBM Corp

10. Imdorf, A., Buehlmann, G., Gerig, L., Kilchenmann, V., Wille, W. (1987): Überprüfung der schätzmethode zur 
Ermittlung der Brutfläche und der Anzahl Arbeiterinnen in Freifliegenden Bienenvölkern. Apidologie, 18(2): 137-146. doi: http://doi.org/10.1051/apido:19870204

11. Imdorf, A., Rickli, M., Kilchenmann, V., Bogdanov, S., Wille, H. (1998): Nitrogen and mineral constituents of honey bee worker brood during pollen shortage. Apidologie, 29: 315-325.

doi: http://doi.org/10.1051/apido:19980402

12. Khoury, D.S., Barron, A.B., Myerscough, M.R. (2013): Modelling Food and Population Dynamics in Honey Bee Colonies. PLOS ONE, 8(5): e59084.

doi: http://dx.doi.org/10.1371/journal.pone.0059084

13. Madras-Majewska, B., Jasinski, Z., Jojczyk, A., Korfant, F. (2005): Effect of early supplemental feeding honeybee colonies with a substitute of bee bread made of drone brood candy, glucose and honey on colony strength. Journal of Apicultural Science, 49(1): 41-46.

14. Mattila, H.R., Otis, G.W. (2006): Influence of pollen diet in spring on development of honey bee (Hymenoptera: Apidae) colonies. Journal of Economic Entomology, 99(3): 604-613.

doi: http://dx.doi.org/10.1603/0022-0493-99.3.604

15. Puškadija, Z. (2011): Promjene u sezonskoj strukturi medova kontinentalne Hrvatske kao posljedica klimatskih promjena. In Zbornik sažetaka Prve nacionalne konferencije o strategiji vrednovanja kakvoće meda, Opatija, Croatia, p. 49-56.
16. Ruttner, F. (1988): Biogeography and Taxonomy of Honeybees. Berlin: Springer Verlag.

17. Saffari, A., Kevan, P.G., Atkinson, J.L. (2010): Palatability and consumption of patty-formulated pollen and pollen substitutes and their effects on honeybee colony performance. Journal of Apiculture Science, 54(2): 63-71.

18. Schmidt, L.S., Schmidt, O.J., Rao, R., Wang, W., Xu, A. (1995): Feeding preference and survival of young worker honey bees (Hymenoptera: Apidae) fed rape, sesame, and sunflower pollen. Journal of economic entomology, 88(6): 1591-1595.

doi: http://dx.doi.org/10.1093/jee/88.6.1591

19. Schulz, D.J., Huang, Z.Y., Robinson, G.E. (1998): Effects of colony food shortage on behavioral development in honey bees. Behavioral Ecology and Sociobiology, 42: 295-303.

doi: http://dx.doi.org/10.1007/s002650050442

20. Seeley, T.D., Visscher, P.K. (1985): Survival of honeybees in cold climates: the critical timing of colony growth and reproduction. Ecological Entomology, 10: 81-88.

doi: http://dx.doi.org/10.1111/j.1365-2311.1985.tb00537.x

21. Standifer, L.N., Haydak, M.H., Mills, J.P., Levin, M.D. (1973): Influence of pollen in artificial diets on food consumption and brood production in honey bee colonies. American Bee Journal, 113: 94-95.

doi: https://doi.org/10.1603/0022-0493-99.3.604

\section{PRIHRANA U KASNU ZIMU STIMULIRA BRZI RAZVOJ ZAJEDNICA SIVE PČELE (Apis mellifera carnica)}

\section{SAŽETAK}

Zbog klimatskih promjena došlo je do promjena u strukturi i intenzitetu medonosnih paša. Ove promjene posljedično izazivaju neravnotežu u podjeli zadataka radilica u pčelinjoj zajednici što dalje uzrokuje spor proljetni razvoj i slabo iskorištavanje proljetnih pčelinjih paša. Kako bi se ubrzao proljetni razvoj potrebno je izvršiti tehnološku mjeru prihrane pčelinjih zajednica pogačama. U istraživanju je bila analizirana sama potreba prihrane ali i sastav pogača (peludna zamjenica i pčelinja pelud). Formirane su tri skupine sa po deset pčelinjih zajednica - kontrolna, prihranjivana pogačom s pčelinjom peludi (P) i peludnom zamjenicom (S). Između 22.2.2016. i 4.4.2016. obavljena su tri kontrolna mjerenja tijekom kojih je utvrđen broj pčela, količina legla i masa pčelinjĭh zajednica. Istraživanje je pokazalo opravdanost provođenja tehnološke mjere prihrane pčelinjih zajednica u kasnu zimu s ciljem poticanja brzog proljetnog razvoja. Naime, kod završnog mjerenja u travnju rezultati su pokazali statistički značajne razlike između $K$ skupine, s jedne strane i skupina $P$ i $S$, s druge strane, u svim mjerenim pokazateljima. Prihranjivane zajednice skupina $P$ i $S$ imale su statistički značajno veću neto masu pčelinjih zajednica, veći broj pčela $i$ više stanica legla. Rezultati ovog istraživanja potvrđuju kako je tehnološku mjeru prihrane u kasnu zimu potrebno provoditi na svim komercijalnim pčelinjacima koji su pripremljeni za proizvodnju meda, peludi, matične mliječi, matica pčela i pčelinjeg otrova.

\section{Ključne riječi: prihrana, medonosna pčela, proljetni razvoj pčelinjih zajednica}

